\title{
THE COMPETITIVENESS OF SERBIAN AGRO-FOOD SECTOR ${ }^{1}$
}

\author{
Sanja Đukič², Mirela Tomaš-Simin ${ }^{3}$, Danica Glavaš-Trbičc ${ }^{4}$
}

\begin{abstract}
The authors analyzed the the competitiveness of agro-food sector of Serbia. The main objectives of this research were: (1) determining the competitive position of the agro-food sector in Serbia within the European Union, and (2) identifying compatibility between the export of Serbian agro-food sector and import requests for the same products in the European Union. In this research, indices of comparative advantage (RCA, ARCA and $R C$ ) have been applied in order to identify the competitiveness of agro-food sector in Serbia. Considering the European Union is most important trade partner of Serbia, the paper gives a review of the complementarity of export products from the agro-food sector of Serbia, with imports of the same products to the EU. The authors conclude that the comparative advantages of agro-food sector in Serbia do not reflect the actual competitive position, and suggest key guidelines for its improvement.
\end{abstract}

Keywords: Serbia, Europe union, agro-food sector, Competitiveness, Revealed Comparative Advantages, Trade complementarity.

JEL: $F 1, Q 17$.

\section{Introduction}

Agriculture is one of the most important economic branches in the Republic of Serbia, taking into account the availability of natural and human resources. Economic structure

1 The article is the result of research within the project financed by the Ministry of Education, Science and Technological Development, Republic of Serbia, Sustainable agriculture and rural development aimed at reaching the strategic objectives of the Republic of Serbia in the Danube region, No III 46006, project period 2011-2017.

2 Sanja Đukić Ph.D., University of Novi Sad, Faculty of Agriculture, Department of Agricultural Economics and Rural Sociology, Dositeja Obradovića Square no. 8, 21000 Novi Sad, Serbia, Phone: +381 66421 845, E-mail: sanja.djukic@polj.edu.rs.

3 Mirela Tomaš-Simin M.Sc., Teaching Assistant, University of Novi Sad, Faculty of Agriculture, Department of Agricultural Economics and Rural Sociology, Dositeja Obradovića Square no. 8, 21000 Novi Sad, Serbia, Phone: +381 21485 3514, E-mail: mirelat@polj.uns.ac.rs.

4 Danica Glavaš-Trbić M.Sc., Teaching Assistant, University of Novi Sad, Faculty of Agriculture, Department of Agricultural Economics and Rural Sociology, Dositeja Obradovića Square no. 8, 21000 Novi Sad, Serbia, Phone: +381 638878 701, E-mail: danicagt@polj.uns.ac.rs.

EP 2017 (64) 2 (723-737) 
that is mainly dependent on agriculture has a significant impact on the structure, volume and tendencies in foreign trade of Serbia. In 2009, Serbia applied for EU membership, a candidate status was granted in 2012. Taking this into account, this paper explores the competitive position of the Republic of Serbia in foreign trade, as well as the complementarity of export of Serbian agro-food products, in the context of its aspirations towards accession to the European Union. The analysis included EU member states that are in the immediate neighbourhood of Serbia: Romania, Bulgaria, Croatia and Hungary, that also have a similar geo-strategic location and relatively similar patterns of economic development. For this purpose four indexes has been applied: RCA, ARCA and RC as indexes of comparative values, and $\mathrm{Sx}_{j} \mathrm{~m}_{\mathrm{k}}$ as index of complementarity of trade values. The main objective of this study was to identify the current competitive position of Serbian agro-food sector within the framework of the European Union. Additional aim of this paper is identification of similarities in the exports of Serbian agro-food to import requirements of the same products in the European Union.

\section{Materials and Methods}

The empirical analysis was based on the use of three indices: Revealed Comparative Advantage (RCA), Additive Revealed Comparative Advantage (ARCA) and Revealed Competitiveness (RC) in order to identify the comparative advantages of agro-food sector in Serbia, while for the purpose of determining the compatibility of trade the merchandise trade complementarity index was used.

A common measure used in the context of the analysis of foreign trade and comparative advantages is Revealed Comparative Advantage Index (RCA). Leisner (1958) was first to introduce the concept of revealed comparative advantages, better known as the Balassa index (Balassa, 1965), which further developed this measure. RCA or Balassa index is primarily used to identify strong and weak export sectors of the certain country. Revealed Comparative Advantage index (RCA) is calculated by the following formula (Balassa, 1965):

$$
R C A=\left(X_{i j} / X_{b}\right)-\left(X_{w i} / X_{w}\right)
$$

where:

$X_{i j}$ is the export of $j$ product (sector) of the country $i ; X_{B}$ is total exports of the country $i$; $X_{w i}$ is global exports of $j$ product (sector), and $X_{w}$ is total global exports. The values of RCA index which are higher than one indicate that the observed country has a comparative advantage in a given sector, while values less than one imply a lack of comparative advantages of a country in a given sector.

Besides the RCA index, there are numerous alternative measurements of comparative advantage. One of these is the determination of Additive Revealed Comparative Advantage index (ARCA). This index was suggested by Hoen and Oosterhaven (2006), and they pointed out that this index has a greater stability in relation to the index of RCA. ARCA index is calculated by the following formula: 


$$
A R C A=\left(X_{A j} / X_{A}\right)-\left(X_{R E F j} / X_{R E F}\right)
$$

where:

$X_{A j}$ is the export of sector $j$ in country $A ; X_{A}$ is the total export of country; $X_{R E F j}$ is the export of sector $j$ of the reference countries; $X_{R E F}$ is the total export of sector reference countries. The value of this index can range from -1 to +1 . When the value of this index is greater than 0 , the country has a comparative advantage in the sector $\mathrm{j}$, while the lack of comparative advantage is determined when this index is lower than 0 .

In the analysis of the comparative advantages of agro-food sector in Serbia, Revealed Competitiveness index (RC) was used, defined by Vollrath and Voo (1998). It reflects how well a country competes in a particular commodity compared with all other commodities and with the rest of the world (Vollrath, Voo, 1988). This index is known as "exportimport" RCA (EIRCA), which is defined as a country's ratio of exports to imports of a particular commodity to the ratio of world exports to world imports of that commodity (Vlachos, 2011). This index is calculated by the following formula:

$$
R C=\ln \left(X_{i j} / X_{T j} / X_{i W} / X_{T W}\right)-\ln \left(M_{i j} / M_{T j} / M_{i W} / M_{T W}\right)
$$

where:

$X_{i j}$ is the exports of product $i$ of country $j ; X_{T j}$ is total exports of country; $X_{i W}$ is the world exports of product $i ; X_{T W}$ is total world exports; $M_{i j}$ is the imports of product $i$ of country $j$; $M_{T j}$ is total imports of country $j ; M_{i W}$ is the world imports of product $i ; M_{T W}$ is total world imports. As in the case of RCA index, index values greater than 1 indicate comparative advantages, and index lower than 1 shows the lack of comparative advantage.

In order to identify how the structure of export partner (Serbia, Romania, Bulgaria, Croatia and Hungary) corresponds with the structure of the import partners (Europe union 28), it was used the merchandise trade complementarity index. This index is also known as the Michaely's bilateral trade-complementarity index or index of compatibility, which represents a modified version of the index of trade similarity and the trade of intensity (Michaely, 1996). This index was calculated using the formula for a single product or a total export:

$$
S_{x_{j} m_{k}}=1-\frac{\sum_{i}\left|x_{i j}-m_{i k}\right|}{2}
$$

where:

$\mathrm{Sx}_{\mathrm{j}} \mathrm{m}_{\mathrm{k}}=$ Michaely's bilateral trade-complementarity index;

$\mathrm{x}_{\mathrm{ij}}=$ share of $\operatorname{good} i$ in total exports of country $j$;

$\mathrm{m}_{\mathrm{ik}}=$ share of good $i$ in total imports of country $k$.

The value of this index ranges from 0 to 1 , and if the value of the index closer to 1 , it is more likely that the countries covered by this analysis, are the ideal trade partners. 
Analyses were performed in order to determining the degree of comparative advantages of the agro-food sector in Serbia, as well as the degree of complementarity of trade. Data on Serbia were compared to the neighbouring countries which are members of the European Union: Romania, Bulgaria, Croatia and Hungary. United Nations Conference on Trade and Development database (UNCTAD) was used, where the classification of products is categorized in groups according to the Standard International Trade Classification (SITC), Revision 3. For the agro-food sector the data marked as All food items (SITC $0+1+22+$ 4, Food and live animals, Beverages and tobacco, Oil seeds and fruits oleaginous; Animal and vegetable oils, fats and waxes) were used. The data on exports and imports for selected countries are related to the period from 2007 to 2015 and they are expressed in US dollars. In UNCTAD there is no record of external trade for Serbia in 2007, so the values of the index of comparative advantages are related to the period 2008-2015.

Initial hypotheses were defined according to the selected objectives of this work:

- There are revealed comparative advantages in the agro-food sector of Serbia in relation to the importance of the agriculture as the most dominant economic sector;

- Considering the importance of of the European Union as the most important Serbian foreign trade partner, there is a correspondence between the structure of Serbian export and import structure of the European Union in terms of agro-food products.

\section{Results and Discussion}

\section{Main characteristics of agro-food sector - Observations for Serbia in the context of EU accession}

In the immediate neighbourhood of Serbia there are four countries that are members of the European Union: Romania, Bulgaria, Croatia and Hungary. Besides of European integration processes, these countries have a similar geo-strategic location and relatively similar patterns of economic development.

Agriculture in Serbia is one of the most important economic sectors. Compared to neighbouring countries which are EU member states, Serbia stands out by highest share of agriculture in gross value added, and by the high share of exports of agricultural products (table 1).

If we take into account the fact that in Serbia there is a high proportion of economically active agricultural population and a relatively high proportion of agricultural land in the total land (only Romania has a higher value for both indicators), attitude about the importance of agriculture in Serbia is completed. ${ }^{5}$

Export structure of Serbia is unfavourable. According to Marković (2010), “... in the last two decades, the dominant group in the structure of Serbian exports has been the primary

5 Considering the fact that Serbia and Montenegro stopped to exist in the context of the common state since May 2006, 2007was elected as the initial period of observation. 
product or products of lower stages of finalization (agricultural products, nonferrous metals and iron, timber, etc.)".

The export structure is one of the reasons of negative trade balance in Serbia (table 2). During the period under review (2007-2015), a high foreign trade deficit was observed in Romania, Bulgaria and Croatian. Hungary in the group of observed countries was the only country that realized foreign trade surplus since 2009.

Table 1. Agricultural Indicators for selected countries

\begin{tabular}{|c|c|c|c|c|c|c|c|c|c|c|}
\hline \multirow[t]{2}{*}{ Countries } & \multicolumn{2}{|c|}{$\begin{array}{c}\text { Agriculture, } \\
\text { forestry and } \\
\text { fishing } \\
\text { (\% of total } \\
\text { GVA)* }\end{array}$} & \multicolumn{2}{|c|}{$\begin{array}{c}\text { Share of } \\
\text { Agriculture } \\
\text { in Exports } \\
(\%)^{* *}\end{array}$} & \multicolumn{2}{|c|}{$\begin{array}{c}\text { Share of } \\
\text { Agriculture } \\
\text { in Imports } \\
(\%)^{* *}\end{array}$} & \multicolumn{2}{|c|}{$\begin{array}{c}\text { Share of } \\
\text { Agricultural } \\
\text { Land in Total } \\
\text { Land }(\%)^{* * * *}\end{array}$} & \multicolumn{2}{|c|}{$\begin{array}{c}\text { Share of } \\
\text { Population } \\
\text { Employed in } \\
\text { Agriculture in } \\
\text { Total } \\
\text { Employment } \\
(\%) * * * *\end{array}$} \\
\hline & 2007 & 2014 & 2007 & 2014 & 2007 & 2014 & 2007 & 2014 & 2007 & 2014 \\
\hline Serbia & 10.0 & 9.3 & 20.65 & 21.60 & 7.12 & 9.13 & 57.8 & 58 & 20.8 & 19.8 \\
\hline Romania & 5.5 & 5.3 & 5.86 & 12.69 & 7.30 & 10.10 & 59.3 & 60.4 & 25.8 & 25.4 \\
\hline Bulgaria & 5.4 & 5.3 & 10.40 & 17.96 & 6.98 & 10.35 & 47.1 & 46 & 7.2 & 6.9 \\
\hline Croatia & 4.8 & 4.3 & 14.04 & 17.98 & 9.14 & 14.19 & 21.5 & 23.3 & 10.7 & 8.7 \\
\hline Hungary & 4.0 & 4.5 & 7.25 & 9.78 & 5.25 & 7.03 & 64.8 & 59 & 4.6 & 4.6 \\
\hline
\end{tabular}

Source: *World DataBank, **World Trade Organization, ***UNdata,**** International Labour Organization

Table 2. Foreign trade balance for selected countries (2008-2014)

\begin{tabular}{|l|r|r|r|r|r|}
\hline Year & $\begin{array}{r}\text { Serbia } \\
\text { (in thousands } \\
\text { of dollars) }\end{array}$ & $\begin{array}{r}\text { Romania } \\
\text { (in thousands of } \\
\text { dollars) }\end{array}$ & $\begin{array}{r}\text { Bulgaria } \\
\text { (in thousands of } \\
\text { dollars) }\end{array}$ & $\begin{array}{r}\text { Croatia } \\
\text { (in thousands of } \\
\text { dollars) }\end{array}$ & $\begin{array}{r}\text { Hungary } \\
\text { (in thousands of } \\
\text { dollars) }\end{array}$ \\
\hline $\mathbf{2 0 0 7}$ & $-9,728$ & $-29,681$ & $-11,510$ & $-13,469$ & -69 \\
\hline $\mathbf{2 0 0 8}$ & $-11,903$ & $-33,426$ & $-14,530$ & $-16,603$ & -574 \\
\hline $\mathbf{2 0 0 9}$ & $-7,702$ & $-13,635$ & $-6,838$ & $-10,713$ & 5,299 \\
\hline $\mathbf{2 0 1 0}$ & $-6,939$ & $-12,593$ & $-4,752$ & $-8,256$ & 7,317 \\
\hline $\mathbf{2 0 1 1}$ & $-8,082$ & $-13,673$ & $-4,328$ & $-9,351$ & 9,847 \\
\hline $\mathbf{2 0 1 2}$ & $-7,695$ & $-12,355$ & $-6,044$ & $-8,465$ & 8,740 \\
\hline $\mathbf{2 0 1 3}$ & $-5,940$ & $-7,571$ & $-4,806$ & $-9,190$ & 9,068 \\
\hline $\mathbf{2 0 1 4}$ & $-5,765$ & $-8,011$ & $-5,353$ & $-9,063$ & 9,085 \\
\hline $\mathbf{2 0 1 5}$ & $-4,850$ & $-9,253$ & $-3,486$ & $-7,733$ & 9,792 \\
\hline
\end{tabular}

Source: International trade center

During the observed period, it was noted that in the export structure of the agro-food 
sector in Serbia by products that have lower added value and a lower level of finalization (table 3) dominates. This structure of exports was the result of unfavourable development tendencies in Serbian agriculture, such as:

- The current extent and structure of agricultural production in Serbia, its high extensiveness, oscillatory, low productivity (resulted from multi-decade disinvestment), along with inefficient organization of production, represent basic factors which limit the competitiveness of domestic producers and exporters on the international market of agro-food products (Paraušić et al., 2013).

- Products which are mostly manufactured in Serbia at the moment are raw materials and semi-manufactured goods which are then exported in order to be finally processed somewhere else, as well as agricultural and food products (Knežević et al., 2012).

- Serbia is characterized by the balance deficit in livestock products, low usage per capita and decreased export. Food production capacities are unequally equipped (Raičević, 2012).

- Serbia's performance with respect to diversification is comparable to that of the surrounding countries, since it is under the influence of almost identical factors: unfavourable position of the agrarian sector and rural areas in developmental policies, low asset accumulation capabilities of rural households, unfavourable capital market and uncertain investment environment, limited market for the placement of products and services by rural areas, inadequately educated human resources, with low level of private entrepreneurship potential (Bogdanov, Vasiljević, 2010).

Table 3. Top 10 export agricultural products from Serbia which are exported to the world (2008-2015)

\begin{tabular}{|l|r|r|}
\hline $\begin{array}{l}\text { Products exported } \\
\text { (Harmonized System Code-4 digits) }\end{array}$ & $\begin{array}{l}\text { Average export } \\
\text { (in thousands of } \\
\text { dollars) }\end{array}$ & $\begin{array}{l}\text { Share in total } \\
\text { exports (\%) }\end{array}$ \\
\hline Maize (not including sweet corn), unmilled & 360,380 & 3.04 \\
\hline Fruit, preserved, and fruit preparations (no juice) & 167,690 & 2.70 \\
\hline Sugar, molasses and honey & 153,523 & 1.41 \\
\hline Fixed vegetable fats \& oils, crude, refined, fractio. & 131,045 & 1.10 \\
\hline Fruits and nuts (excluding oil nuts), fresh or dried & 109,957 & 0.93 \\
\hline Cereal preparations, flour of fruits or vegetables & 101,760 & 0.86 \\
\hline Non-alcoholic beverages & & \\
\hline
\end{tabular}




\begin{tabular}{|l|l|l|}
\hline $\begin{array}{l}\text { Products exported } \\
\text { (Harmonized System Code-4 digits) }\end{array}$ & $\begin{array}{l}\text { Average export } \\
\text { (in thousands of } \\
\text { dollars) }\end{array}$ & $\begin{array}{l}\text { Share in total } \\
\text { exports (\%) }\end{array}$ \\
\hline Feeding stuff for animals (no unmilled cereals) & 101,626 & 0.86 \\
\hline Edible products and preparations & 100,300 & \\
\hline Wheat (including spelt) and meslin, unmilled & 97,545 & \\
\hline
\end{tabular}

Source: Author`s calculations from United Nations Conference on Trade and Development database

\section{Comparative Advantage - comparative analysis for Serbia, Romania, Bulgaria, Croatia and Hungary}

International trade of any country is of great importance because it provides the opportunity to specialize in those production fields in which it has the best performance. Typical causes of exchange are the differences in production factors (land, labour, natural resources and capital), as well as production technology between countries. Comparative advantages are a key concept in explanation of specialization in the exports of goods (Hadziev, 2014). Innovations are important for the production specialization of countries. According to Porter (1990), “..., ,companies achieve competitive advantage through acts of innovation. Innovation can be manifested in a new product design, a new product process, a new marketing approach, or a new way of conducting training". Freebairn (1987) defines competitiveness as an indicator of the market's ability to supply products and services in a particular place in the required form, at a certain time towards customer needs at a price that is equal to or better than its competitors, but there is a possibility of earnings at least opportunity costs. Porter (1990) argues that true national competitiveness is measured by productivity, and national productivity will only rise if a nation expands exports of products or services that it can produce productively.

The question arises what are the export performance of the agro-food sector in Serbia and the four neighbouring countries in terms of competitiveness, and what is the possible position of Serbia? For the observed period (2007-2015) greater competitive advantage of agro-food sector was observed in Serbia in relation to all regional competitors that are members of the EU. RCA index values for Serbia, mainly range from 2.406 in 2013 to 3.128 in 2012, RC index values are 0.91 in 2013 and 1.347 in 2009, ARCA index values are 0.104 in 2008 and 1.160 in 2012 (reference countries - world) and ARCA index values are 0.091 in 2013 and 0.144 in 2012 (reference countries - EU28).

After Serbia, Bulgaria is in the observed period stands out at relatively high levels of RCA, RC and ARCA indexes. Unlike Serbia and Bulgaria, the comparative advantage of 
the agro-food sector, Hungary and Croatian was the least noticed (chart 1, 2, 3, 4).

Chart 1. RCA index for Serbia and selected countries for total agricultural products (1997-2015)

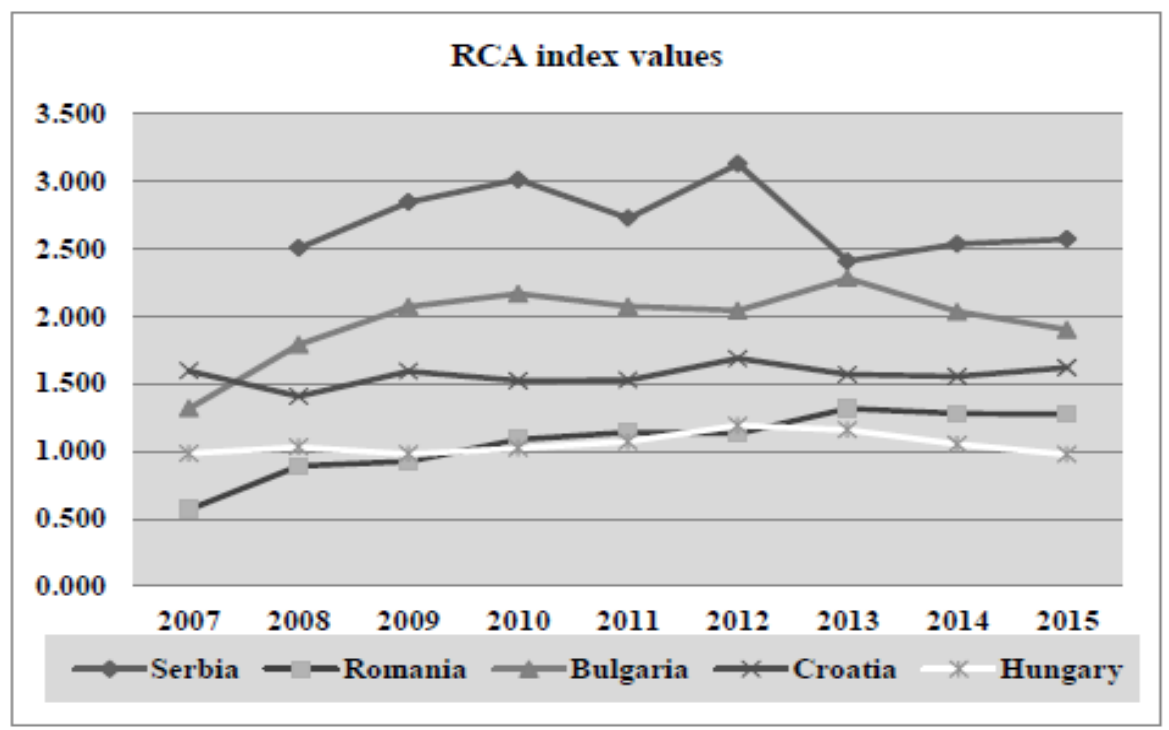

Source: Author`s calculations from United Nations Conference on Trade and Development database

Chart 2. RC index for Serbia and selected countries for total agricultural products (19972015)

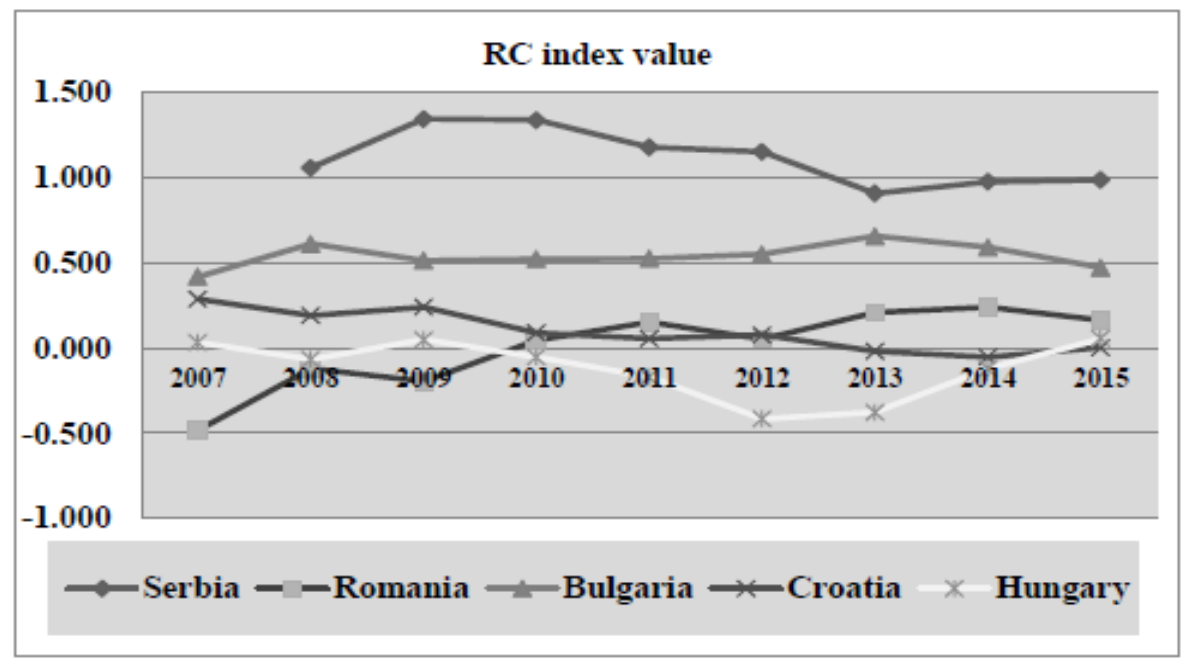

Source: Author`s calculations from United Nations Conference on Trade and Development database 
Chart 3. ARCA index for Serbia and selected countries for total agricultural products with reference countries-world and (b) reference countries-Europe union 28 (2007-2015)

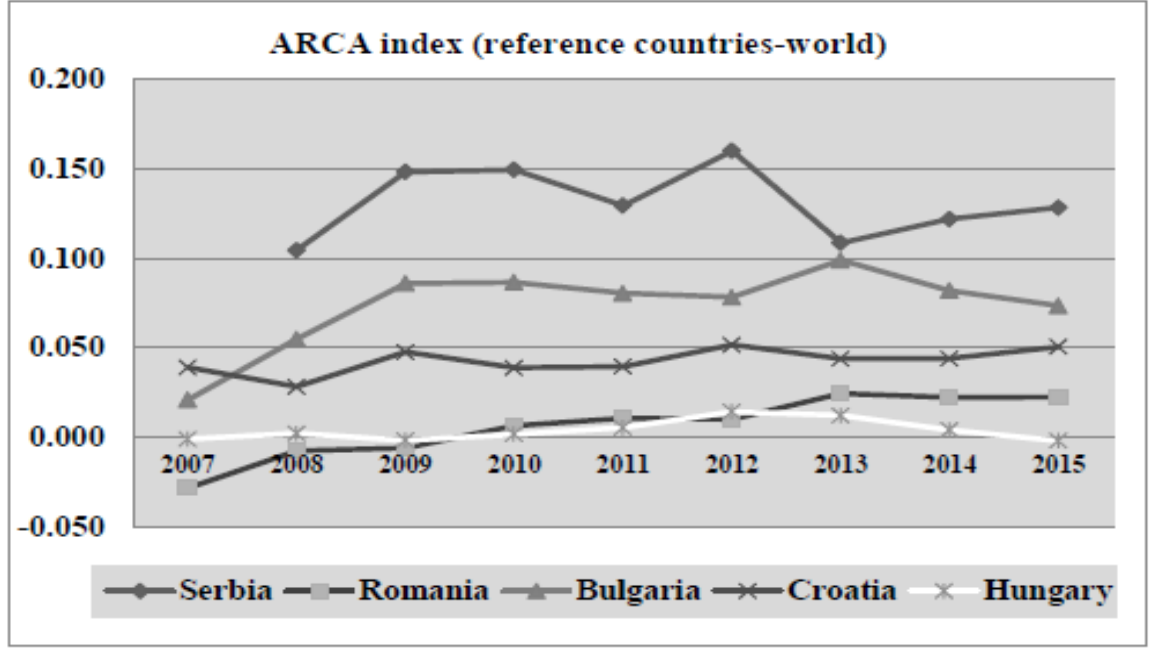

Source: Author `s calculations from United Nations Conference on Trade and Development database

Chart 4. ARCA index for Serbia and selected countries for total agricultural products with references countries-Europe union 28 (2007-2015)

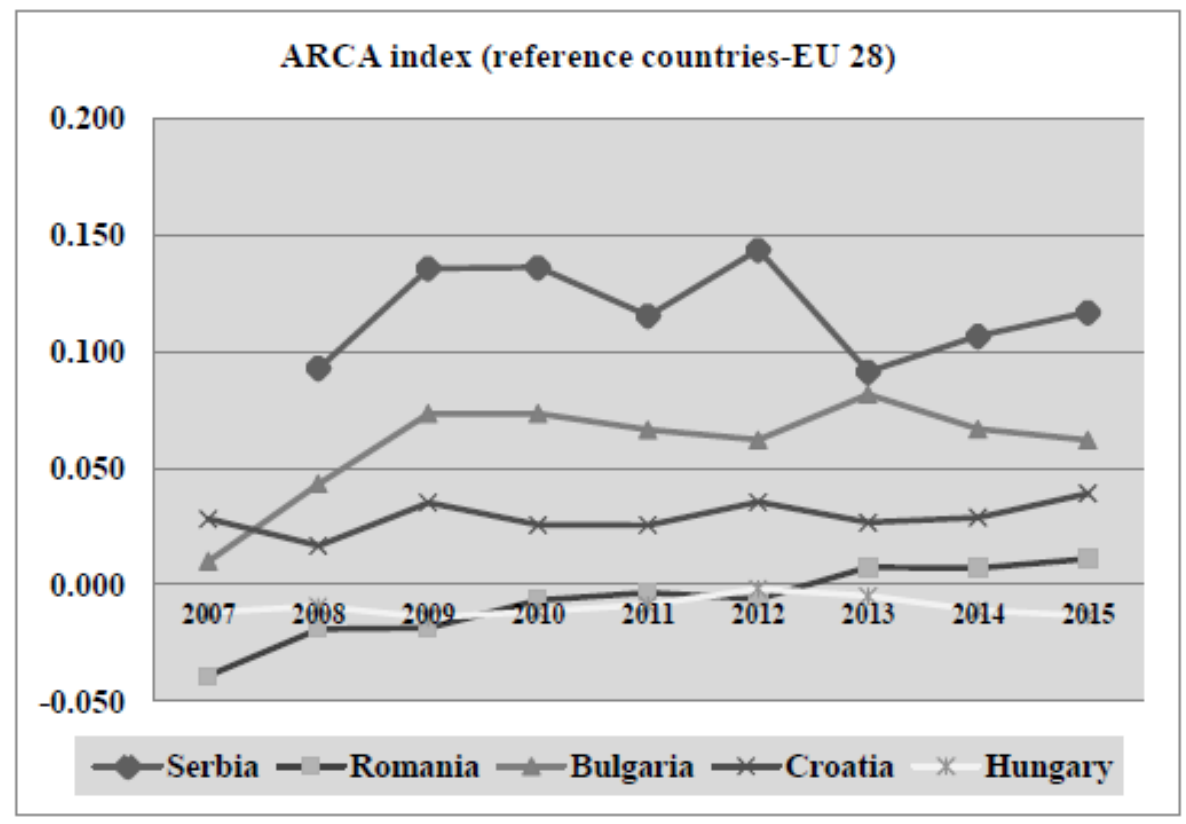

Source: Author `s calculations from United Nations Conference on Trade and Development database 
High levels of RCA, RC and ARCA indexes for Serbia for Serbia show significant competitive advantages of agro-food sector. These values are higher than in neighboring countries which are members of the European Union, and they are the result of a significant share of agriculture in gross value added, as well as the high share of exports of agricultural products. In contrast, the export structure of agro-food product from Serbia is unfavourable (raw materials and products with a small degree of the processing).

\section{Trade complementarity for agro-food products - comparative analysis for Serbia, Romania, Bulgaria, Croatia and Hungary}

Bearing in mind that Stabilisation and Association Agreement between Serbia and EU came into force in 2013, adapting the structure of merchandise exports in line with the import demand of EU member states is of great importance. The successful integration of Serbia into the European Union will also depend on its export competitiveness. If one observes the export position of Serbia and its EU regional competitors, it can be seen that their most important foreign trade partner is European Union (table 4).

In a foreign trade exchange between Serbia and the European Union (EU 28), there are preferential trade conditions. The question arises what is the complementarity of the exchange of products from the agro-food sector in Serbia (and the neighbouring EU member states) and the European Union (EU 28). In the literature individual opinions can be found which are related to the theme of complementarity in international merchandise trade (Drysdale, Garnaut, 1982; Michaely, 1996; Khandelwal, 2004, Lukauskas et al., 2013), as a phenomenon of correspondence between exports of one country and imports of another country.

Table 4. Top 5 export destination for selected countries (2015)

\begin{tabular}{|c|c|c|c|c|c|}
\hline \multirow{2}{*}{$\begin{array}{l}\text { Observed } \\
\text { countries }\end{array}$} & \multicolumn{5}{|c|}{ Top 5 export destination } \\
\hline & 1 & 2 & & 4 & 5 \\
\hline Serbia & EU (28) & Bosnia and Herzegovina & $\begin{array}{c}\text { Russian } \\
\text { Federation }\end{array}$ & Montenegro & $\begin{array}{c}\text { FYR } \\
\text { Macedonia }\end{array}$ \\
\hline Romania & EU (28) & Turkey & $\begin{array}{c}\text { United } \\
\text { States } \\
\end{array}$ & $\begin{array}{c}\text { Russian } \\
\text { Federation }\end{array}$ & Moldova \\
\hline Bulgaria & EU (28) & Turkey & China & Serbia & $\begin{array}{l}\text { Russian } \\
\text { Federation }\end{array}$ \\
\hline Croatia & $\mathrm{EU}(28)$ & Bosnia and Herzegovina & Serbia & $\begin{array}{l}\text { United } \\
\text { States }\end{array}$ & $\begin{array}{c}\text { Russian } \\
\text { Federation }\end{array}$ \\
\hline Hungary & EU (28) & United States & Turkey & China & $\begin{array}{c}\text { Russian } \\
\text { Federation }\end{array}$ \\
\hline
\end{tabular}

Source: International trade center 
Table 5. Michaely's bilateral trade-complementarity index for agricultural products for selected countries (2007-2015)

\begin{tabular}{|l|r|r|r|r|r|r|r|r|r|}
\hline $\begin{array}{l}\text { Observed } \\
\text { countries }\end{array}$ & $\mathbf{2 0 0 7}$ & $\mathbf{2 0 0 8}$ & $\mathbf{2 0 0 9}$ & $\mathbf{2 0 1 0}$ & $\mathbf{2 0 1 1}$ & $\mathbf{2 0 1 2}$ & $\mathbf{2 0 1 3}$ & $\mathbf{2 0 1 4}$ & $\mathbf{2 0 1 5}$ \\
\hline Serbia & $* 1$ & 0.953 & 0.933 & 0.931 & 0.941 & 0.927 & 0.954 & 0.946 & 0.942 \\
\hline Romania & 0.980 & 0.991 & 0.990 & 0.997 & 0.999 & 0.998 & 0.996 & 0.996 & 0.995 \\
\hline Bulgaria & 0.995 & 0.978 & 0.964 & 0.963 & 0.966 & 0.968 & 0.959 & 0.966 & 0.970 \\
\hline Croatia & 0.986 & 0.991 & 0.983 & 0.986 & 0.986 & 0.981 & 0.987 & 0.985 & 0.981 \\
\hline Hungary & 0.994 & 0.996 & 0.992 & 0.995 & 0.997 & 1.000 & 0.998 & 0.995 & 0.993 \\
\hline
\end{tabular}

Source: Author `s calculations from United Nations Conference on Trade and Development database

In the analyzed period, the recorded values of Michaely's bilateral trade complementarity index indicate relatively high compatibility exports of the agrofood sector of Serbia, Romania, Bulgaria, Croatia and Hungary with imports of the European Union (table 5). The highest compatibility was observed in Hungary, which in 2012 made a perfect complementarity in foreign trade with the European Union. Despite the fact that the values of this index for Serbia are close to 1, it still has the lowest compatibility in the foreign trade of agro-food products with the EU 28 in relation to the observed countries.

The structure of exports of the agro-food sector in Serbia (which is intended for the EU market) is based on the domination of products from crop production (table 6). Livestock products are not present in the top ten major agro-food products exported from Serbia. Serbia has the possibility of exporting beef meat (baby beef) under preferential conditions in the European Union, but its realization is seriously endangered due to the long-term reduction of cattle production. The total average annual production of beef for the past twenty years in Serbia was about 110,000 tons, with a tendency of decline, especially in recent years, and the latest data show that it is about 80,000 tons (Petrović et al., 2013). Bearing this in mind, further improvement of the structure of Serbian exports of agro-food products from Serbia should be based on greater participation of livestock products, as well as other agro-food products with a higher degree of processing. This improvement of the export structure of agro-food products from Serbia would have an impact on the achievement of greater complementarity Serbia's foreign trade with European Union in the next period. 
Table 6. Top 10 export agricultural products which are exported from Serbia to EU (20082015)

\begin{tabular}{|l|r|}
\hline Serbia & $\begin{array}{r}\text { Average export } \\
\text { (in thousands of dollars) }\end{array}$ \\
\hline Maize (not including sweet corn), unmilled & 289,148 \\
\hline Fruit, preserved, and fruit preparations (no juice) & 286,973 \\
\hline Sugar, molasses and honey & 143,716 \\
\hline Fixed vegetable fats \& oils, crude, refined, fractio & 102,188 \\
\hline Wheat (including spelt) and meslin, unmilled & 59,730 \\
\hline Feeding stuff for animals (no unmilled cereals) & 48,843 \\
\hline Vegetables & 43,151 \\
\hline Edible products and preparations & 32,877 \\
\hline Fruits and nuts (excluding oil nuts), fresh or dried & 28,012 \\
\hline Cereal preparations, flour of fruits or vegetables & 25,332 \\
\hline
\end{tabular}

Source: United Nations Conference on Trade and Development database

\section{Conclusions}

Results shown in this research are very important because they show the position of the agro-food sector in Serbia. In this context, in this research were used RCA, ARCA and $\mathrm{RC}$ indices to identify the revealed comparative advantages of agro-food sector in Serbia. The values of of these indexes are positive in Serbian agro-food sector in the period from 2007 until 2015. The values of of these indexes are calculated for EU member countries that are in the immediate neighbourhood of Serbia: Romania, Bulgaria, Croatia and Hungary, because of similar geo-strategic location and relatively similar patterns of economic development. In relation to these countries, Serbia has significantly higher values of RCA, RC and ARCA indexes. Despite the expressed comparative advantages of Serbia, the structure of exports of the agro-food sector of Serbia is unsatisfactory (raw material, products with a small level of finalization, small share of livestock products). This example of Serbia shows how expressed comparative advantages are not simultaneously a reflection of the strong competitive position, but rather a reflection of the "vitality" of the sector. In addition, the authors examined the values of the merchandise trade complementarity index in order to identify how the structure of export partner (Serbia, Romania, Bulgaria, Croatia and Hungary) corresponds with the structure of the import partners (Europe union 28). Research results showed that there are great compatibility exports of agro-food sector of Serbia with imports of the European Union, but in relation to the observed countries Serbia has the lowest values. The authors conclude that further improvement of the competitiveness of the agro-food sector of Serbia and its better positioning in the European Union, depends on several factors, such as: the integration of Serbia to WTO, strengthening the quality of products from the agro-food sector, and improvement and harmonization of the structure of exports of the agro-food sector in accordance with the import requirements of the European Union. 


\section{References}

1. Balassa, B. (1965): Trade Liberalization and Revealed Comparative Advantage. The Manchester School, The University of Manchester, Vol. 33, No. 2, pp. 99-123, Manchester, England.

2. Bogdanov, N., Vasiljević, Z. (2011): Role of Agriculture and Multifunctional Rural Development in Serbia. Applied Studies in Agribusiness and Commerce-APSTRACT, Agroinform Publishing House, Vol. 1-2, pp. 47-56. Budapest, Hungary, (available at: $\quad$ http://ageconsearch.umn.edu/bitstream/104642/2/6 Bogdanov_Role $\% 200 f \% 20$ Agriculture Apstract.pdf).

3. Drysdale, P., Garnaut, R. (1982): Trade intensities and the analysis of bilateral trade flows in a many-country world: a survey, Hitotsubashi Journal of Economics, Hitotsubashi University, Vol. 22, No. 2, pp. 62-84, Tokyo, Japan, (available at: https://core.ac.uk/ download/pdf/6835665.pdf).

4. Freebairn, J. (1987): Implications of Wages and Industrial Policies on Competitiveness of Agricultural Export Industries, Review of Marketing and Agricultural Economics, Australian Agricultural and Resource Economics Society, Vol. 55, No. 1, pp. 14-22, Sydney, Australia.

5. Hadzhiev, V. (2014): Overall Revealed Comparative Advantages. Eurasian Journal of Economics and Finance, Eurasian Publications, Vol 2, No. 1, pp. 47-53, Istanbul, Turkey, (available at: http://eurasianpublications.com/pdf/ejocaf/EJEF-4.pdf).

6. Hoen, A. R., Oosterhaven, J. (2006): On the measurement of comparative advantage. The Annals of Regional Science, Springer Verlag, Vol. 40, No. 3, pp. 677-691, Berlin, (available at: http://www.regroningen.nl/oosterhaven/doc/ARS'06\%20Balassa.pdf).

7. International Labour Organization (ILO), (available at: http://www.ilo.org/global/ statistics-and-databases/lang--en/index.htm).

8. International trade center (ITC), (available at: http://www.intracen.org/itc/market-infotools/trade-statistics.

9. Khandelwal, P. (2004): COMESA and SADC: prospects and challenges for regional trade integration. Working Paper No. 04/227. International Monetary Fund. Washington, D.C, (available at: https://pdfs.semanticscholar.org/4e34/03b8c1b52bf2fbe9b337aac201 ef69c7b5bc.pdf).

10. Knežević, I., Gajić, M., Ivanović, K. (2012): Serbia, European Union, Russia - an Analysis of Economic Relations. European Movement, Belgrade. Serbia, (available at: http://www.emins.org/uploads/useruploads/forum-it/Serbia-EU-Russia.pdf).

11. Liesner, H. H. (1958): The European common market and British industry. The Economic Journal, Wiley-Blackwell for the Royal Economic Society (United Kingdom) vol. 68, no. 270, pp. 302-316, Oxford, United Kingdom.

12. Lukauskas, A., Stern, R. M., Zanini, G. (2013): Handbook of trade policy for development. ISBN 978-0-19-968040-5, Oxford University Press, Oxford, United Kingdom. 
13. Marković, I. (2010): Improvement of Serbian export competitiveness. Facta Universitatis, Series: Economics and Organization, University of Niš, Vol. 7, No. 3, pp. 271-278, Niš, Serbia.

14. Michaely, M. (1996): Trade preferential agreements in Latin America: an ex ante assessment. Policy Research Working Paper No. 1583, The World Bank, Washington DC, (available at: http://documents.worldbank.org/curated/en/934301468773398976/ pdf/multi0page.pdf).

15. Paraušić, V., Simeunović, I. Vuković, D. B. (2015): Serbian agricultural competitiveness. Geography, Environment, Sustainability, Faculty of Geography, Lomonosov Moscow State, University and Institute of Geography of the Russian Academy of Sciences, Vol. 1, pp. 16-26, Moscow, Russia, (available at: https://www.researchgate.net/ profile/Darko_Vukovic/publication/285629911_SERBIAN_AGRICULTURAL COMPETITIVENESS/links/56bdc20608aedb6510d18eb0.pdf\#page=16).

16. Petrović, M. M., Aleksić, S., Petrović, M. P., Petrović, M., Pantelić, V., Novaković, Ž., Ružić-Muslić, D. (2013): Potentials of Serbian livestock production: Outlook and future. Biotechnology in Animal Husbandry, Institute for Animal Husbandry, BelgradeZemun, Vol. 29, No. 1, pp. 1-17, (available at: http://www.doiserbia.nb.rs/img/doi/14509156/2013/1450-91561301001P.pdf).

17. Porter, M. E. (1990): The Competitive Advantage of Nations. Harvard Business Review, Harvard University, Vol. 68, pp. 73-93, USA.

18. Raičević, V., Ignjatijević, S., Matijašević, J. (2012): Economic and legal determinants of export competitiveness of the food industry of Serbia. Industrija, Ecconomics institute, Belgrade, vol. 40, No. 1, pp. 201-226, Belgrade, Serbia.

19. The United Nations Staitistics Division (Undata), (available at: http://data.un.org).

20. United Nations Conference on Trade and Development database (UNSTADstat), (available at: http://unctadstat.unctad.org/EN/Index.html.

21. Vlachos, I. P. (2001): Comparative advantage and uncertainty in the international trade of Mediterranean agricultural products. Medit, Istituto Agronomico Mediterraneo, Bari Vol. 12, No. 4, pp. 42-49, Bari, Italia, (available at: http://www.iamb.it/share/img new medit articoli/493 42vlachos.pdf).

22. Vollrath, T. L., Vo, D. H. (1988): Investigating the Nature of World Agricultural Competitiveness. Tech. Bull. No. 1754, United States Department of Agriculture. Washington, DC.

23. World DataBank, (available at: http://databank.worldbank.org/data/reports. aspx?source $=$ world-development-indicators).

24. World Trade Organization (WTO), (available at: https://www.wto.org/english/res e/ statis e/statis e.htm).

25. Yeats, A. J. (1998): What can be expected from African regional trade arrangements?: Some empirical evidence. Policy Research Working Papers No. 2004, The World Bank, Washington, D.C. 


\title{
KONKURENTNOST AGROINDUSTRIJSKOG SEKTORA SRBIJE6
}

\author{
Sanja Đukič ${ }^{7}$, Mirela Tomaš-Simin ${ }^{8}$, Danica Glavaš-Trbic ${ }^{9}$
}

\begin{abstract}
Apstrakt
Autori u radu analiziraju konkurentnost agroindustrijskog sektora Srbije. Glavni ciljevi istraživanja bili su: (1) utvrđivanje konkurentske pozicije agroindustrijskog sektora Srbije u okviru Evropske unije; (2) utvrđivanje kompatibilnosti između izvoza agroindustrijskog sektora Srbije i uvoznih zahteva za istim proizvodima u Evropskoj uniji. U istraživanju su primenjeni indeksi komparativnih prednosti (RCA, ARCA i RC) u cilju identifikacije konkurentnosti agroindustrijskog sektora Srbije. S obzirom da je Evropska unija najvažniji trgovinski partner Srbije, u radu je dat osvrt na komplementarnost izvoza proizvoda iz agroindustrijskog sektora Srbije sa uvozom istih proizvoda u EU. Autori zaključuju da su prisutne značajane komparativne prednosti agroindustrijskog sektora Srbije, ali one nisu odraz stvarne konkurentske pozicije, i predlažu ključne smernice za njeno unapređenje.
\end{abstract}

Ključne reči: Srbija, Evropska unija, agroindustrijski sektor, konkurentnost, otkrivene komparativne prednosti, komplementarnost spoljne trgovine.

6 Ovaj rad je rezultat istraživanja u okviru projekta Ministarstva za nauku i tehnološki razvoj Republike Srbije pod nazivom „Održiva poljoprivreda i ruralni razvoj u funkciji ostvarivanja strateških ciljeva Republike Srbije u okviru dunavskog regiona“, broj projekta TR 46006.

7 Dr Sanja Đukić, Univerzitet u Novom Sadu, Poljoprivredni fakultet, Departman za ekonomiku poljoprivrede i sociologiju sela, Trg Dositeja Obradovića br. 8, 21000 Novi Sad, Srbija, Telefon: +38166421 845, E-mail: sanja.djukic@polj.edu.rs.

8 Mirela Tomaš-Simin M.Sc., Asistent, Univerzitet u Novom Sadu, Poljoprivredni fakultet, Departman za ekonomiku poljoprivrede i sociologiju sela, Trg Dositeja Obradovića br. 8, 21000 Novi Sad, Srbija, Telefon: +381 21485 3514, E-mail: mirelat@polj.uns.ac.rs.

9 Danica Glavaš-Trbić M.Sc., Asistent, Univerzitet u Novom Sadu, Poljoprivredni fakultet, Departman za ekonomiku poljoprivrede i sociologiju sela, Trg Dositeja Obradovića br. 8, 21000 Novi Sad, Srbija, Telefon: +381 638878 701, E-mail: danicagt@polj.uns.ac.rs.

EP 2017 (64) 2 (723-737) 